\title{
JUURNAL.RU
}

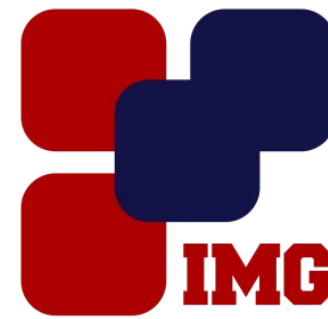

IVanoy
Management
Group

Гришина Н.И.

Калужский государственный университет им. К. Э. Циолковского

Калуга, Россия

doi: 10.18411/lj-31-03-2017-1-07

idsp 000001:lj-31-03-2017-1-07

\section{Изображённый мир в литературной сказке и его изучение в курсе литературного чтения в начальной школе}

Дефиниция «художественный мир произведения» (иногда называемый как «поэтическим» или «внутренним») укоренена в литературоведении различных стран. В России данное понятие было обосновано Дмитрием Сергеевичем Лихачевым.

Важнейшие свойства мира произведения - его нетождественность первичной реальности, участие вымысла в его создании, использование писателями не только жизнеподобных, но и условных форм изображения[1].

Дмитрий Сергеевич взял во внимания соотнесение произведения с действительностью, творческий характер ее отражения. Мир произведения - это художественно освоенная и преображенная реальность. Сам мир является многоплановым. Самые крупные единицы словесно-художественного мира - это персонажи, которые составляют систему, и события, из которых в дальнейшем слагаются сюжеты. Далее мир произведения включает в себя, то, что можно назвать компонентами изобразительности: акты поведения персонажей, черты их наружности (портреты), явления, психики, а также факты окружающего людей бытия (вещи, подаваемые в рамках, интерьеров; картины природы пейзажи). И малым неделимым звеном художественной предметности являются единичные подробности (детали) изображаемого.

Чтобы было удобно анализировать художественный мир произведений все детали можно разделить на несколько групп. Сначала выделяются детали внешние и психологические. Внешние детали представляют читателю внешнее, предметное бытие людей, их наружность и среду обитания.

Психологические детали знакомят нас с внутренним миром человека, персонажа, это могут быть его отдельные душевные движения: мысли, чувства, переживания, желания и т.п

Детализация и конкретизация в предметном мире не просто интересна, важна, желательна, - она является неизбежной, составляя суть образа. Ведь 
воссоздать предмет во всех его особенностях (а не просто упомянуть о нем) автор не способен, и именно деталь, совокупность деталей «замещают» в тексте целое, вызывая у читателя нужные автору ассоциации. Писатель при этом полагается на воображение читателя, его жизненный опыт, добавляющего мысленно недостающие элементы описываемого. Отбирая, изображая детали чего - либо в произведении писатель как бы поворачивает предметы к читателю определенной стороной.

Данная модель мира произведения у разных писателей своеобразна; сами изображенные миры в различных литературных произведениях очень разнообразны и могут или в большей или в меньшей степени быть похожими на реальный мир. Но в любом случае следует помнить, что перед нами созданная писателем художественная реальность, не тождественная реальности первичной.

\section{Литература}

1. Андреев, А. Н. Целостный анализ литературного произведения [Текст]/ А. Н. Андреев. - Минск: Гревцово, 2010. - 415 с.

2. Есин, А. Б. Принципы и приемы анализа литературного произведения [Текст]/ А. Б. Есин. - М., 2000. - 248 с.

3. Лихачев Д.С. Внутренний мир художественного произведения[Текст]/ Д. С. Лихачев/ Вопросы литературы. - 1968. - № 8.

4. Поспелова, Г. Н. Введение в литературоведение [Текст]/ Г. Н. Поспелова. - М., 2001. $145 \mathrm{c}$.

5. Страхов, И. В. Психологический анализ в литературном творчестве [Текст]/ И. В. Страхов. - Саратов, 2002. - $300 \mathrm{c}$.

6. Тюпа, В. И. Анализ художественного текста [Текст]/ В. И. Тюпа. - М.: Академия, 2009. $-336 \mathrm{c}$. 